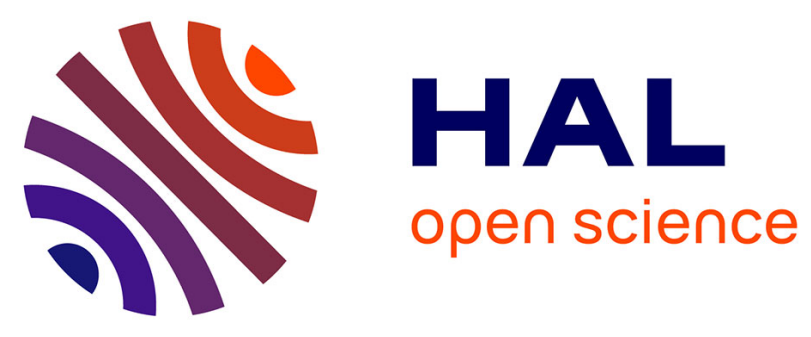

\title{
High-Content Screening of Plankton Alkaline Phosphatase Activity in Microfluidics
}

Mathias Girault, Thomas Beneyton, Deniz Pekin, Lionel Buisson, Sabrina Bichon, Celine Charbonnier, Yolanda del Amo, Jean-Christophe Baret

\section{- To cite this version:}

Mathias Girault, Thomas Beneyton, Deniz Pekin, Lionel Buisson, Sabrina Bichon, et al.. High-Content Screening of Plankton Alkaline Phosphatase Activity in Microfluidics. Analytical Chemistry, 2018, 90 (6), pp.4174 - 4181. 10.1021/acs.analchem.8b00234 . hal-01757331

\section{HAL Id: hal-01757331 \\ https://hal.science/hal-01757331}

Submitted on 26 Mar 2021

HAL is a multi-disciplinary open access archive for the deposit and dissemination of scientific research documents, whether they are published or not. The documents may come from teaching and research institutions in France or abroad, or from public or private research centers.
L'archive ouverte pluridisciplinaire HAL, est destinée au dépôt et à la diffusion de documents scientifiques de niveau recherche, publiés ou non, émanant des établissements d'enseignement et de recherche français ou étrangers, des laboratoires publics ou privés. 


\title{
High-content screening of plankton alkaline phosphatase activity in microfluidics
}

\author{
Mathias Girault*1 ${ }^{1}$, Thomas Beneyton ${ }^{1}$, Deniz Pekin ${ }^{1}$, Lionel Buisson ${ }^{1}$, Sabrina Bichon ${ }^{1}$, Céline Char- \\ bonnier $^{2}$, Yolanda del $\mathrm{Amo}^{2}$, Jean-Christophe Baret ${ }^{1}$ \\ 1) CNRS, Univ. Bordeaux, CRPP, UMR5031, 33600 Pessac, France. \\ 2) CNRS, Laboratoire d'Environnements et Paléoenvironnements Océaniques et Continentaux (EPOC), UMR 5805, 33615 \\ Pessac, France.
}

This paper is the author version of the paper published as:

High-content screening of plankton alkaline phosphatase activity in microfluidics,

M. Girault et al. Anal. Chem. 2018

https://doi.org/10.1021/acs.analchem.8b00234

\begin{abstract}
One way for phytoplankton to survive to orthophosphate depletion is to utilize the dissolved organic phosphorus by expressing alkaline phosphatase. The actual methods to assay the alkaline phosphate activity - either in bulk or as a presence-absence of enzyme activity - fail to provide information on individual living cells. In this context, we develop a new microfluidic method to compartmentalize cells in 0.5 nanoliter water-in-oil droplets and measure the alkaline phosphatase activity at the single cell level. We use the enzyme labelled fluorescence (ELF), which is based on the hydrolysis of ELF-P substrate, to monitor in real-time and at the single cell level both qualitative and quantitative information on cell physiology (i.e. the localization and number of active enzyme site, the alkaline phosphatase kinetics). We assay the alkaline phosphatase activity of Tetraselmis sp. as a function of the dissolved inorganic phosphorus concentration and show that the time-scale of the kinetics spans one order of magnitude. The advantages of sub-nanoliter scale compartmentalization in droplet-based microfluidics provide a precise characterization of a population with a single cell resolution. Our results highlight the key role of cell physiology to efficiently access to dissolved organic phosphorus.
\end{abstract}




\section{Introduction}

Phytoplanktons are located at the base of the trophic web and play a major role in the biological production of the Oceans. ${ }^{1,2}$ These unicellular organisms are responsible for roughly $40 \%$ of the inorganic carbon fixation on Earth, underlying their significance in climate control. ${ }^{3}$ The increase of ocean stratification accompanying climate change suggests that mixing rates of deep nutrient-rich layers with surface nutrient-depleted waters decrease at a world wide scale. ${ }^{4-6}$ The ocean stratification leads to the decrease of nutrient concentrations in the surface layer and limits the phytoplankton growth. Phytoplankton is known to develop strategies to survive to these oligotrophic conditions. ${ }^{7}$ The activation of specific metabolic pathways to use organic matter increases the sources of nutrients available in the water column. ${ }^{8,9}$ As a consequence, the expression of enzymes linked to the physiological condition of the cells characterizes a stress in nutrient for numerous plankton species. ${ }^{10-14}$ Among these enzymes, the alkaline phosphatase is reported to be expressed under orthophosphate starvation in some basins and its activity is used as an indicator of orthophosphate limitation. ${ }^{15-18}$

Alkaline phosphatase activity (APA) is mainly measured in bulk or as a presence-absence of enzyme activity using soluble substrates and enzyme labelled fluorescence (ELF) methods. ${ }^{19,20}$ Since the pioneer study of the ELF substrate by Nedoma et al.,no simple method effectively links the kinetics of activity to a single living cell. ${ }^{21}$ The lack of a suitable method is in part due to the presence of motile cells in natural sample which are difficult to isolate over - long periods of time. The development of new methods to discriminate organisms and isolate them within their microenvironments is essential to better characterize the role and the activity of enzymes in nutrient uptake.

In this context, microfluidic technology offers numerous advantages to manipulate small volumes of compartmentalized liquid for single cell analysis, including algae. ${ }^{22-25}$ The compartmentalization is also efficiently performed in the form of water-in-oil droplets. ${ }^{26,27}$ These droplets act as micro-reactors to encapsulate single cells and reagents in order to perform complex biological assays such as enzymatic activity measurements at the single cell level. ${ }^{28-31}$ Although the measurement of enzyme activities are already performed at a single droplet level in microfluidics, the kinetics of enzyme catalysis are mainly measured using population of droplets. ${ }^{32-34}$ These methods allow for the screening of cell libraries at a given incubation time but each droplet can not be followed with 
accuracy in the chip. Thus, the kinetics of alkaline phosphatase of a specific organism in a natural sample can not be directly measured. As a consequence, the cellular heterogeneity is hidden in the plankton community.

Here, we develop a new and automatic microfluidic procedure to measure the kinetics of the APA at the single cell level. This microfluidic platform is composed of a droplet maker, an incubation chamber and an image processing system to track droplets of interest and measure their activity as a time-dependent fluorescence signal. Based on the enzyme labelled fluorescence method coupled to time lapse analysis, the detection of the sites of the enzyme becomes accessible.

\section{Materials and methods}

Microalgae culture: The marine microalgae Tetraselmis sp. (F; Stein, 1878) is cultured in culture flasks (30 mL) and clean glass bottles $(1 \mathrm{~L})$ with $\mathrm{F} / 2$ medium at $23{ }^{\circ} \mathrm{C} .{ }^{35,36}$ The bottle is exposed to natural light conditions and is gentle mixed before each sampling. To maintain the culture in axenic conditions, an antibiotic cocktail (250 $\mu \mathrm{g} \cdot \mathrm{mL}^{-1}$ ampicillin, $100 \mu \mathrm{g} \cdot \mathrm{mL}^{-1}$ kanamycin and $50 \mu \mathrm{g} \cdot \mathrm{mL}^{-1}$ streptomycin) is added to cultures. ${ }^{37}$

Microfluidic chip: The microfluidic chip is prepared from PDMS by soft lithography. ${ }^{38}$ The depths of the channels and the traps are $30 \mu \mathrm{m}$ and $40 \mu \mathrm{m}$, respectively. Hydrodynamic traps are designed to fit the volume of droplets $(500 \mathrm{pL})$ and maintained their positions only during the time lapse analysis. The flow is driven using three pressure controlled syringe pumps. ${ }^{39}$ The chip is composed of a flow focussing droplet maker, an oil extractor to remove excess of oil and a large incubation area to trap droplets and perform the time lapse analysis (Figure 1). ${ }^{40,41}$ Droplets of 100 microns in diameter are produced by flow focusing in an oil and surfactant (PicoSurf, Dolomite, $2 \% \mathrm{w} / \mathrm{w})$ solution. The cell density is in all cases much smaller than 1 cell per droplet to avoid multiple encapsulations

Phosphorus measurements: Seawater samples collected from the culture bottle are prefiltered through a disposable $0.2 \mu \mathrm{m}$ syringe filter to discard cultured cells. A set of glass bottles, cleaned with dilute $10 \% \mathrm{HCl}$ and rinsed with ultrapure water, are filled with $10 \mathrm{~mL}$ filtered subsamples for the dissolved inorganic phosphorus (DIP) and the total dissolved phosphorus (TDP) analyses. Glass bottles are tighten caped and frozen $\left(-20^{\circ} \mathrm{C}\right)$. TDP concentrations are measured using classical persulfate-digestion method. ${ }^{42}$ Briefly, Prior to the analysis, bound phosphorus is released from organic matter by adding an oxidation step to the TDP samples. The released orthophosphate is reacted with an acidified molydate reagent and potassium antimonyl tartrate. DIP and TDP concentrations are 
read colorimetrically by the molybdenum blue reaction. ${ }^{43}$ Dissolved organic phosphorus (DOP) is calculated by difference (i.e., TDP-DIP). The detection limit which is estimated as three times of the standard deviation of blank was $0.05 \mu \mathrm{mol} . \mathrm{L}^{-1}$. Due to the small droplet volume, phosphorus measurements are only performed using the culture bottles. According to the reaction time of the alkaline phosphatase ( 120 min), it is assumed that the phosphorus concentration in each droplet is the same as the culture.

Alkaline phosphatase activity in the dissolved fraction: The fluorogenic phosphatase substrate 6,8-difluoro-4methylumbelliferylphosphate (DIFMUP, Molecular probes) is used to measure the alkaline phosphatase activity in the dissolved fraction of the culture. The assay is performed using a series of ten DIFMUP concentrations (50, $75,100,125,175,250,375,500,1.000$ and $1.500 \mu \mathrm{mol} . \mathrm{L}^{-1}$, final concentration in culture) with duplicate samples at each concentration (Figure S1). $10 \mathrm{~mL}$ samples of assayed cultures are filtered on a $0.2 \mu \mathrm{m}$ porosity polycarbonate filters and aliquots are stored protected from light in a freezer $\left(-20^{\circ} \mathrm{C}\right)$ until $\mathrm{P}$ analysis. DIFMUP hydrolysis into 6,8-difluoro-7-hydro-4-methylcoumarin (DIFMU) is monitored on a microtiter plate reader at room temperature according to the manufacturer's recommendations (excitation and emission: 360 and $450 \mathrm{~nm}$, Molecular devices, Spectramax). Blanks (deionised water and samples fixed with $0.5 \%$ glutaraldehyde) are run indicating no significant autohydrolysis of the substrate.
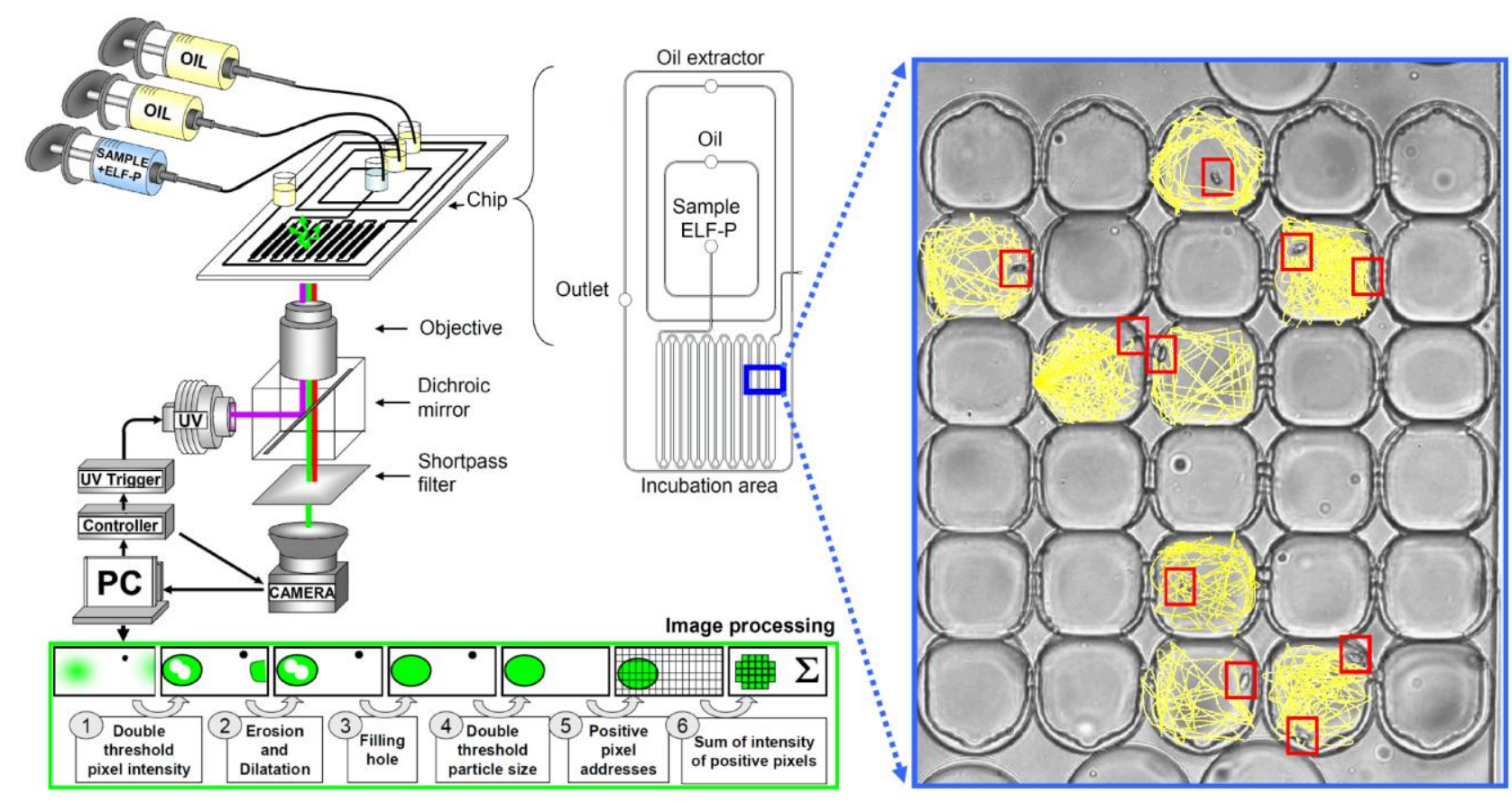

Figure 1: Experimental design and detail of the chip used for the enzyme labelled fluorescence method and incubation of living cells. Droplets are generated by flow-focusing a sample stream with two streams of oil containing 
surfactant. When the incubation area is filled with droplets, the droplet production is stopped and time lapse analysis starts. Every 30 seconds a Red Green Blue (RGB) image of the incubation chamber is captured by the camera and sent to the image processing system. The image processing system extracts the green panel from the RGB images to avoid any contamination from the fluorescence of chlorophyll a (red). The sum of pixel intensity of each single particle detected is returned and stored in a file. The yellow lines show the swimming paths of living planktons (red squares) encapsulated in the droplets.

Alkaline phosphatase activity at a single cell level: The alkaline phosphatase activity is estimated by monitoring change in the fluorescence signal in each droplet of interest (i.e., droplet containing a single living cell). In this study, a living cell is defined as a Tetraselmis cell swimming in the droplet. Fluorescence signal is due to the hydrolysis of ELF-P substrate into a non-fluorescent water-soluble phenol form of ELF alcohol (ELF-A). This ELFA product precipitates into a fluorescent water-insoluble form after the spontaneous formation of an intramolecular hydrogen bond. ${ }^{44}$ Therefore, the quantitative measurement of the alkaline phosphatase activity is based on two main assumptions which are i) the system is in dynamic equilibrium, where the rate of ELF-P hydrolysis equals the rate of ELF-A precipitation ii) the affinity of the cell for the ELF-P substrate depend on the quantity of active enzyme. $^{21,45}$

Endogenous phosphatase substrate (E 6588) is used to prepare the ELF-P solution. Sample containing living plankton $(50 \mu \mathrm{L})$ is injected in the chip reservoir and then ELF-P solution is inoculated (final concentration 41.6 $\mu$ mol.L $L^{-1}$ ). By using a pipette, sample and ELF-P solution are then gentle mixed in order to homogenise the solution. Pumps are then rapidly connected to the chip inlets by using clean plastic tubes. The droplets are generated by flow focusing a sample stream containing the ELF-P solution with two streams of oil containing a surfactant (2\% surfactant in fluorinated oil FC-40, Dolomite). When the incubation chambers are filled with droplets the flow is stopped and time lapse analysis starts. Observations of the labelled cells are performed at a x20 magnification. The fluorescence signal is also converted in nutrient concentration by using the intensity of fluorescence measured in the droplets at the stationary phase. The stationary phase in the fluorescence signal is assumed to be reached when the ELF-P is entirely consumed by the plankton cell in the droplet. 
An ultraviolet LED (365LP1, Nominal wavelength $365 \mathrm{~nm}, 1.150 \mathrm{~mW}$, Thorlabs) is connected to a trigger module (LEDD1B T-Cube, Thorlabs). The trigger is controlled by a homemade LabVIEW software which did the data acquisition system (USB-6008, National Instrument). Bleaching of the fluorescent compounds and death of cells due to long exposure time under harmful short wavelength are minimized by generating short width pulses of UV irradiation. Typically, an exposition of $500 \mathrm{~ms}$ every $30 \mathrm{~s}$ is observed to not induce lysis of Tetraselmis sp. and not significantly modify the intensity of the fluorescent label during up to 1 hour in the chip (Figure S2). By using the spectrofluorometer (Molecular devices, Spectramax), fluorescence spectra of Tetraselmis sp. labelled or not with ELF are measured in order to control the signal ratio of the fluorescence product (ELF) to natural fluorescence (i.e., cell-induced fluorescence; Figure S3). Autohydrolysis of ELF-P substrates in the droplet and initiated by the UV lamp is tested in order to measure any possible modification of the background signal (Figure S4). The localization of alkaline phosphatase sites is also examined using a laser scanning confocal microscope. Observations of cells are performed at a x63 magnification.

A)

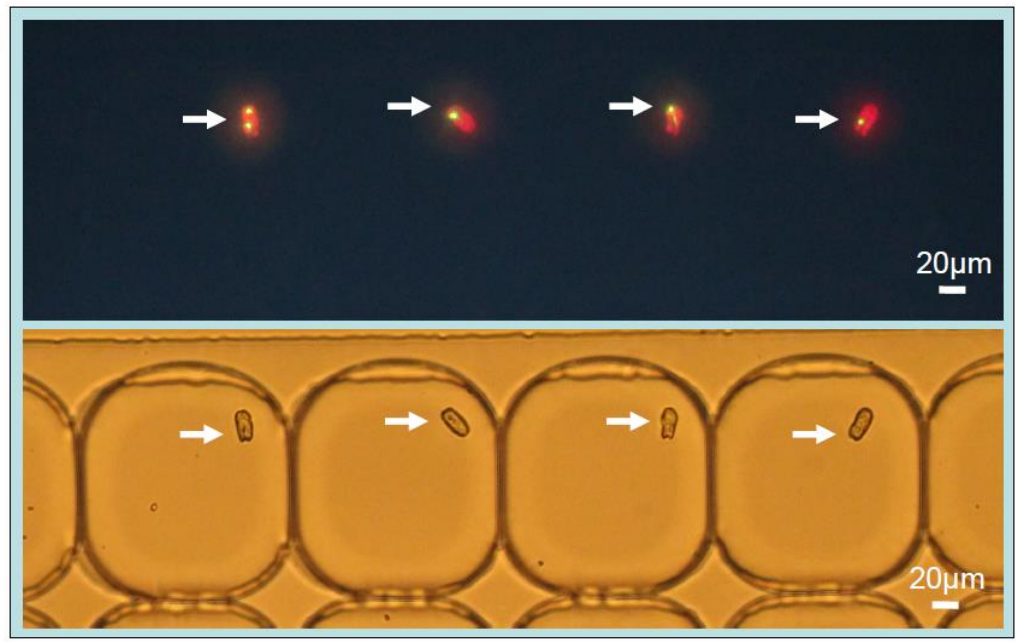

C)
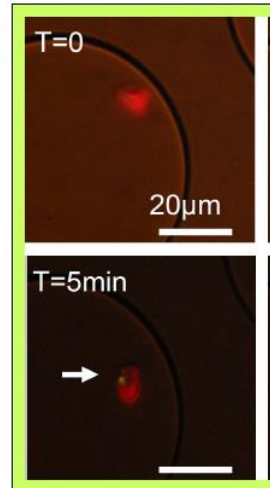
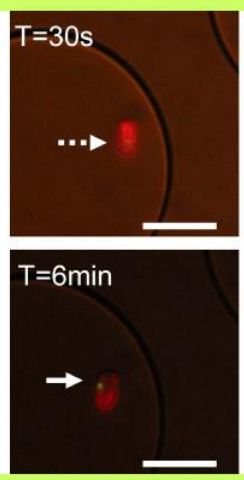
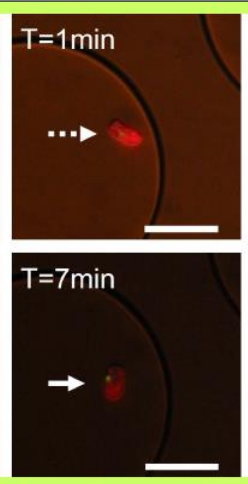
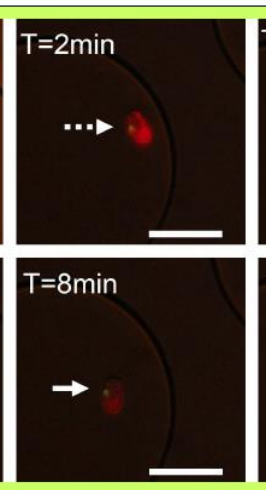

B)
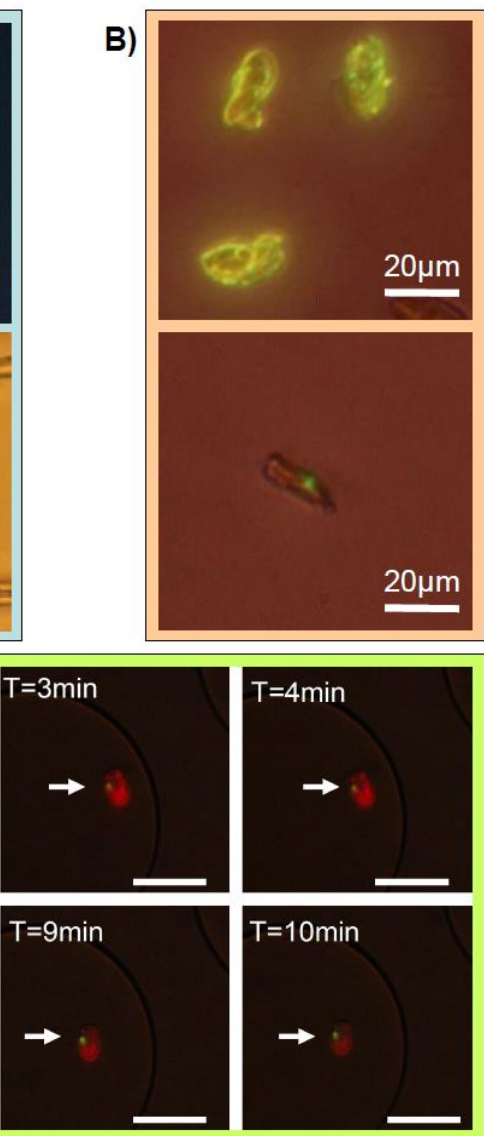

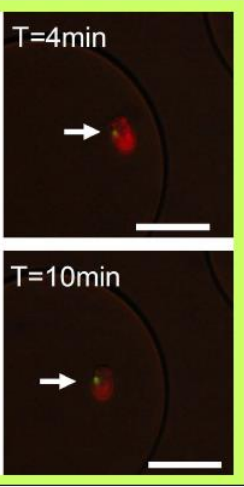

Figure 2: Photomicrographs of labelled cells. The green labels show the enzyme labelled fluorescent compounds located at the alkaline phosphatase sites. Red labels are chlorophyll a pigments. The panel A shows the typical 
fluorescence and bright-field images of four droplets containing single living labelled cells. The panel B shows the difference of labels between three dead cells with numerous labels at the surface (upper image) and a living cell with a single label located at the bottom of the flagellar apparatus (bottom image). The panel C shows an example of the kinetics of a single living cell labelling in droplet.

Vision system for the time lapse analysis: To monitor the labelling kinetic at a single cell level, an original and complete image processing system is developed using NI Vision module of LabVIEW software (National Instrument). The image processing consists in a combination of two programs: i) the automatic picture system controlling the camera settings, ultraviolet LED and extract green panel from every Red Green Blue (RGB) image and ii) the automatic particle detection system. The automatic particle detection system consists in a threshold step to isolate object from the background (i.e., pixel intensity higher than 40 in a 8 bits image), erosion and dilatation steps to discriminate object to the droplet boundary (1 pixel, respectively), a filling hole step to return an area size of each object detected. Parts of cell lysis and salt and pepper noise of the camera are eliminated using low and high thresholds in object area. These thresholds are decided according to the objective and the sizes of the plankton tested. Finally, the image processing system sums the intensity of the 8 bits image for each pixel composing an object. Then, data are stored in a table for data processing.

\section{Results}

Control of motile cells encapsulation and incubation: An integrated microfluidic approach is chosen in order to regroup in a single chip the complete procedure of the fluorescence labelled enzyme activity method. Because of the cell encapsulation, the alkaline phosphatase assay and image processing procedures are directly implemented to easily follow the droplet of interest trapped in the chip (Figure 1). This approach reduces the time of analysis, contamination and production costs. However, each microfluidic channel should work together in a range of stable and strictly controlled flow velocities in order to correctly encapsulate plankton and obtain a suitable chip for enzymatic assay. The encapsulation of motile cells such as flagellate species is mainly limited by their swimming speeds and directions. ${ }^{39}$ In this study, Tetraselmis sp. is observed to swim at counter current meaning that the flow within the microfluidic channel must be faster than their swimming speeds to encapsulate the majority of cells. 
Typically, a droplet production frequency of at least $5 \mathrm{~Hz}$ is observed to be suitable to encapsulate the Tetraselmis sp. cells in 0.5 nanoliter droplets. An oil extractor system is added to locally increase the frequency of droplet generation and improve the cell encapsulation. By decreasing the oil fraction, this system also increases the number of droplets trapped by area in the incubation channel. Hydrodynamic traps are added to delete effect of any residual flow on the droplet of interest during long time incubation. A difference of $10 \mu \mathrm{m}$ between the depths of the traps and the incubation channel is chosen as a balance between effect of flow on the drop, resolution of the soft lithography and focus on the cell in the droplet (Figure S5).

Localization of the alkaline phosphatase sites; According to the fluorescence labelled enzyme method, the localization of the enzyme site is identified during the time lapse analysis. Two different enzyme sites are routinely labelled: i) the basis of the flagellar apparatus where flagella are inserted into the deep apical cell depression ii) near the center of the cell (close to the nucleus) (Figure 2). The cells with a single labelled site are only stained close to the apical cell depression. In contrast to living cell, a high number of labels is observed to cover the surface of dead cells (Figure 2B). Confocal microscopy revealed that labels are more localized in the periphery of living cell rather than inside. However, a diffuse green fluorescence is observed in the region surrounding the nucleus (Figure S6). This diffuse fluorescence is intracellular and is induced by the fluorescence of pigments such as chlorophyll despite the low level of fluorescence measured by spectrofluorometry (Figure S3). Abundance of cells with single or double sites labelled is examined with regards to the dissolved inorganic phosphorus (DIP) concentrations. The results indicated that $18 \pm 6 \%$ of Tetraselmis sp. labelled had a double site stained at a concentration of DIP of $11.3 \mu \mathrm{mol} . \mathrm{L}^{-1}$. At a higher DIP concentration $\left(22.3 \mu \mathrm{mol} . \mathrm{L}^{-1}\right)$, less than $5 \%$ of cells labelled had a double sites stained. At a lower DIP concentration $\left(3.25 \mu \mathrm{mol} . \mathrm{L}^{-1}\right)$, the percentage of cells with a double site labelled increases $(69 \pm 8 \%$ of the total of cells labelled) and suggests that DIP concentration regulates the activation of the site of the alkaline phosphatase in Tetraselmis sp. No statistical difference in the kinetic of labelling is observed depending on the localization of the enzyme sites (Student t-test, $\mathrm{n}=5$ ). Moreover, no lag in labelling kinetics is observed between the sites located at the apical cell depression and near the center of the cell suggesting that labelling at the two sites occur simultaneously.

Kinetics of the alkaline phosphatase at a single cell level; The phosphatase alkaline activity is assayed at the single cell level using the culture of Tetraselmis sp. Labelling of the alkaline phosphatase sites by the fluorescent 
products is observed after a lag period ranged from 0 to $16 \mathrm{~min}$. In this study, the start of the detection of the ELF-A fluorescent product is randomly distributed and no correlation is found between the lag in the labelling kinetic and the kinetics of the APA (Fig 3D-E). The velocity of the enzymatic reaction is measured at the single cell level using the developed microfluidic technology (Figure 3A). The hydrolysis rate of ELF-P substrate per

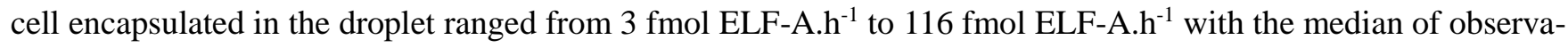
tions at $26 \mathrm{fmol}$ ELF-A.h ${ }^{-1}$ (Figure 3B). In order to test the new microfluidic method under different nutrient conditions, alkaline phosphatase activity of Tetraselmis sp. is measured using the cells cultivated in batch culture during 9 days (Figure 4). The concentration of dissolved inorganic phosphorus (DIP) was high at day D0 (31.1 $\mu \mathrm{mol} . \mathrm{L}^{-1}$ ) and progressively decreases to reach $0.7 \mu \mathrm{mol} . \mathrm{L}^{-1}$ (D9). Concentration of dissolved organic phosphorus (DOP) was maximum the D1 $\left(6.6 \mu \mathrm{mol} . \mathrm{L}^{-1}\right)$ and decreases until the detection limit of the method (D5, D6). From the D7 to D9, DOP is detected and its concentrations ranged from 1.5 to $3.8 \mu$ mol. $\mathrm{L}^{-1}$.

In the early phase of cell growth, the alkaline phosphatase activity measured in the dissolved fraction $(<0.2 \mu \mathrm{m})$ ranged from $1.25 \mu \mathrm{mol} . \mathrm{L}^{-1} \cdot \mathrm{min}^{-1}$ to $1.30 \mu \mathrm{mol} . \mathrm{L}^{-1} \cdot \mathrm{min}^{-1}$ (D0 to D2, respectively). Then, the APA drastically increases from D5 $\left(1.28 \mu\right.$ mol.L-1.min-1) to D7 $\left(1.76 \mu \mathrm{mol} . \mathrm{L}^{-1} \cdot \mathrm{min}^{-1}\right)$ and reached $1.80 \mu \mathrm{mol} . \mathrm{L}^{-1} . \mathrm{min}^{-1}$ and 1.95 $\mu \mathrm{mol} \cdot \mathrm{L}^{-1} \cdot \mathrm{min}^{-1}$ in $\mathrm{D} 8$ and $\mathrm{D} 9$, respectively.

Concentrations of Tetraselmis sp. increased from the D0 $\left(0.3 \times 10^{8}\right.$ cells. $\left.\mathrm{L}^{-1}\right)$ to the $\mathrm{D} 7\left(4.8 \times 10^{8}\right.$ cells. $\left.\mathrm{L}^{-1}\right)$. Then, culture of Tetraselmis sp. showed a decay phase from the D8 $\left(3.9 \times 10^{8}\right.$ cells. $\left.\mathrm{L}^{-1}\right)$ to the D9 $\left(3.2 \times 10^{8}\right.$ cells.L $\left.\mathrm{L}^{-1}\right)$. During this decay phase, cell aggregates are observed in the large culture bottles. The cells show labelling sites only during three days (D4, D5, D6). The percentage of cells labelled in the droplets with respect to the total of cells enumerated in the droplets drastically increases from D4 (3\%) to D6 (78\%). 

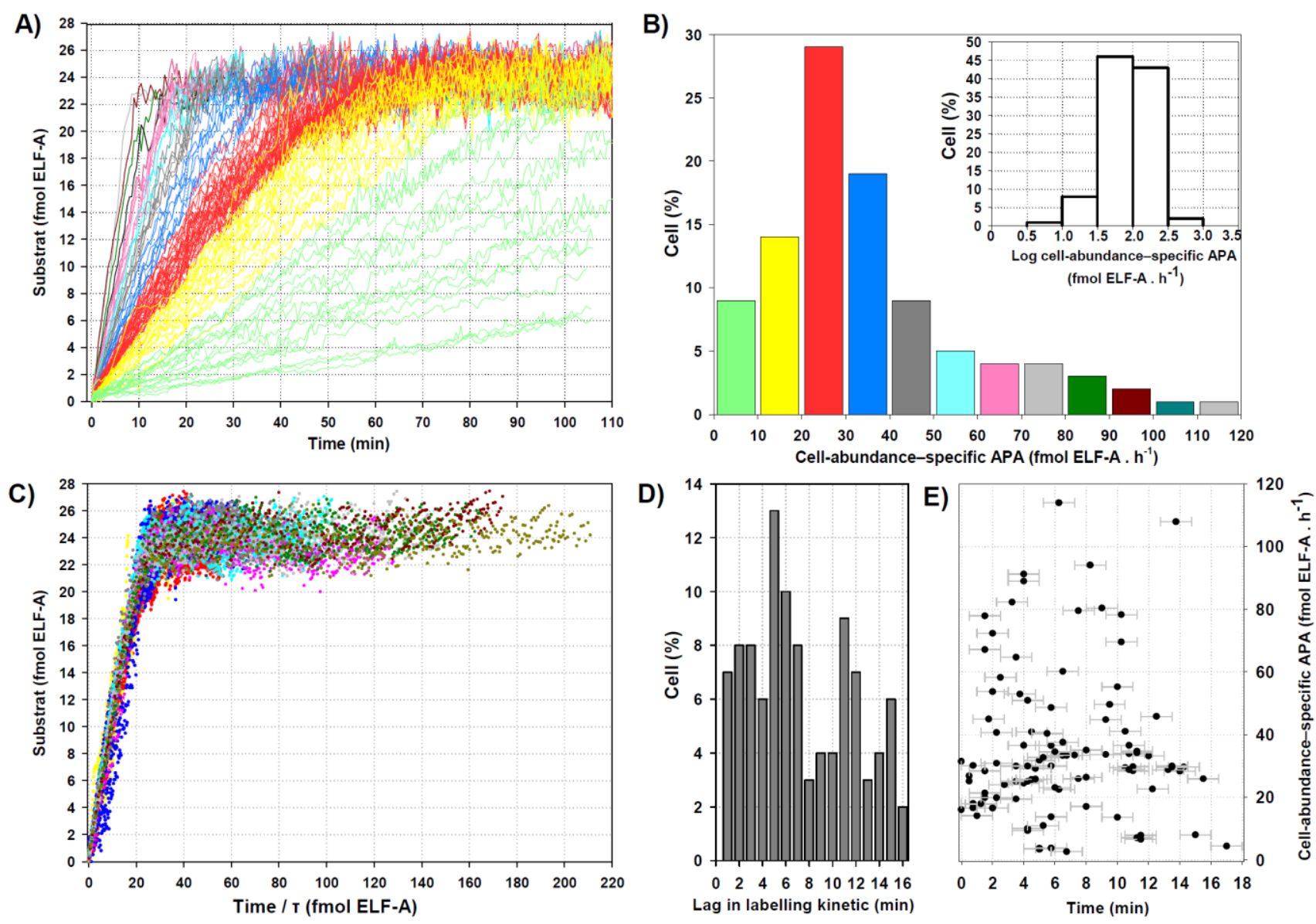

Figure 3: Variability of the labelling kinetics of Tetraselmis sp. under the same environmental conditions. The panel A) shows examples of kinetics of alkaline phosphatase measured at a single cell level. The kinetics are obtained by compiling experiment data collected within a single day and shown without the lag period occurring after the ELF-P addition. The panel B shows the distribution of kinetics of alkaline phosphatase of Tetraselmis sp. ( $n=100$ cells). Histogram in the top right of the panel B shows the $\log 10$ transformed data of the kinetics of alkaline phosphatase of Tetraselmis sp. The panel C shows the concentration of ELF-A as a function of time, rescaled by a cell-dependent time-constant ${ }_{\mathrm{T}}$ showing the master curve of the cell response. The panel $\mathrm{D}$ shows the distribution of the lag in labelling kinetic as a function of time. The panel $\mathrm{E}$ shows the lack of relationship between the lag in labelling kinetic and the kinetic of the alkaline phosphatase activity.

\section{Discussions}

We report here the development of a microfluidic platform to measure the kinetics of alkaline phosphatase activity at the single cell level. To the best of our knowledge microfluidic approach was not yet tested on plankton study. ${ }^{28,46-48}$ The microfluidic technologies offer suitable procedures to trap flagellate cells into nanoliter scale 
droplets and examine droplets of interest using time lapse analysis. In this study, the time lapse analysis is based on an original image processing system to measure the fluorescence signal of the labelled cell. The image processing algorithm mainly consists in the utilization of thresholds and morphological erosion-dilatation to discriminate between labelling and background fluorescence. The use of erosion and dilation steps is chosen to discriminate the fluorescence signal depending on the enzyme sites because it has also proven to be a powerful tool for computer vision tasks such as detection of the edge. ${ }^{49}$ The developed method takes advantage of the camera sensors to detect several sites of enzyme not easily observable by using a single photomultiplier tube and relevant for high-content screening applications. As the intensity of the measured fluorescence signal depends on the position of the ELF-A stains in the droplet, the position of the focal plane in the channel is an important parameter to control. The results obtained indicate that the variation of the fluorescence signal is not linearly correlated to the distance between the focal plane and the ELF-A stain (Figure S5). This lack of linearity is due to the diffraction rings of the ELF-A stain as previously reported when a template matching algorithm is used for the detection of round shaped object. ${ }^{50}$ As a consequence, despite the fact that the fluorescence signal varies of $\pm 10 \%$ through the entire channel, up to $72 \%$ of the measurement of fluorescence had a bias of less than $5 \%$. The position of plankton in the droplet is also a factor controlling the intensity of the fluorescence signal collected by the camera sensors. Especially when the cell swims, its rotation hides the enzyme sites labelled. This oscillation in the fluorescence signal measured is illustrated in kinetics of the figure 3A. Therefore, an optimization of the depth of the channel depending on the size of the target is recommended in order to minimize bias in the measurement of the fluorescence signal.

The present ELF method is based on the hypothesis that the cell affinity for ELF-P substrate depends on the quantity of the active enzyme enable to hydrolyse this substrate. This assumption is critical for a development of a standard method suitable for the most of phytoplankton species. In the literature, González-Gil et al., observed that Isochrysis galbana showed a higher fluores-cence as compared to Amphidinium sp. when using ELF-P substrate but this is not the case with others soluble substrates tested. ${ }^{45}$ They concluded that ELF-P substrate is not hydrolyzed equally by all alkaline phosphatases. However, this variability in fluorescence intensity observed for Isochrysis galbana can also be due to the difference of affinity between ELF-P and the other soluble substrates. 
For instance, Nedoma et al., and Van Wambeke et al., reported that generally extracellular phosphatases displayed higher affinity for the soluble substrate (4-methyllumbelliferyl phosphate, 4MUP) than for ELF-P substrates. ${ }^{19,51}$

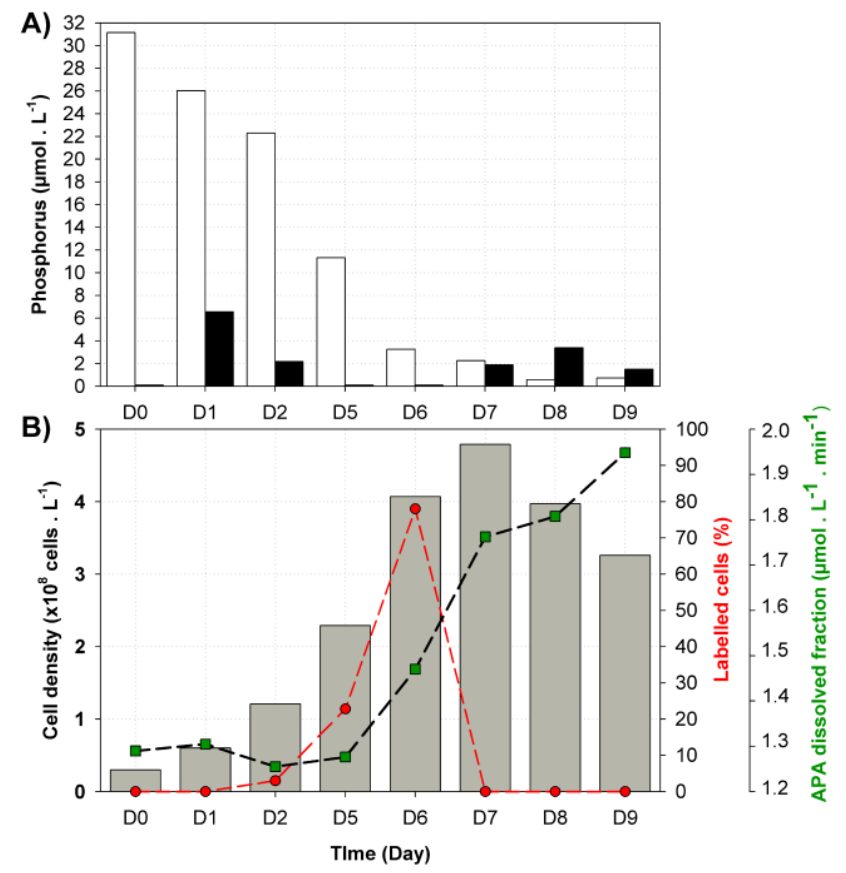

Figure 4: Percentage of labelled cells depending on the phosphate concentration as a function of time. The upper panel A shows the concentrations of dissolved inorganic phosphorus and dissolved organic phosphorus (white and black bars, respectively). The bottom panel B shows the concentration of cells (grey bars), the percentage of labelled cells in droplets (red dotted line) and the alkaline phosphatase activity in the dissolved fraction (green dotted line) as a function of time (9 days).

Moreover, methods based on soluble substrates measure the APA in bulk and can include also exoenzymes secreted in the medium by phytoplankton species. ${ }^{52-57}$ Therefore, a low APA at the cell surface due to the release of the enzyme in the medium can lead to a low ELF label at cell surface but a high APA in the medium as reported for some cell cultures. ${ }^{58}$ Imbalance between exoenzyme and transmembrane enzyme activities could lead to the variation of fluorescence intensity observed at the species level. For these reasons, we assume that hydrolysis of the ELF-P substrate mainly depends on the quantity of alkaline phosphatase per cell in this present study. 
By using a single microfluidic device, qualitative and quantitative information of the alkaline phosphatase activity are obtained at every analysis (i.e., localization of the enzyme sites, number of active sites per cell, number of labelled cells and velocity of the reaction). The single cell analysis revealed that a high variability of velocity (over 1 order of magnitude) is measured under the same culture conditions (Figure 3B). Two sites of alkaline phosphatase are routinely labelled in the periphery of the living cell. These results differed from the literature reports where numerous ELFA fluorescent stains are observed in Tetraselmis sp. growing under P-depleted laboratory cultures. ${ }^{15,59}$ The low number of labelled sites is linked to the possibility of targeting the droplets containing living cells and the absence of permeabilization step in the ELF protocol used herein. Permeabilized cells can have both an intracellular and extracellular labelling and lead to an increase of the number of site stained by the ELFA compounds. ${ }^{10,21,59,60}$ Confocal microscopy tends to confirm that the localization of the labelled sites of the alkaline phosphatase is more extracellular than intracellular in Tetraselmis sp. (Figure S6). Despite that the presence of the label at the cell periphery is not ubiquitous among the species, this localization of the alkaline phosphatase is commonly observed in the literature. ${ }^{61-65}$ Results obtained on the number of labelled sites of alkaline phosphatase depending on the DIP concentration suggested that Tetraselmis sp. increases the number of active sites under DIP starvation (up to two different sites). Activation of the site located near the centre of the cell does not seem to be induced by the saturation of the site located at the apical cell depression since the labelling kinetic occurs simultaneously. However, mechanisms of regulation of alkaline phosphatase activity appear to be complex, especially since some cells did not express alkaline phosphatase activity at their surface even at very low DIP concentration. Moreover, some cells had double sites labelled in spites of the high concentration of DIP measured in the culture medium $\left(22.3 \mu \mathrm{mol} . \mathrm{L}^{-1}\right)$. This concentration of DIP, at which alkaline phosphatase activity is first detected, was higher than Tetraselmis chui $\left(13.6 \mu \mathrm{mol} . \mathrm{L}^{-1}\right)$ but in the range of other groups of phytoplankton listed in Lin et al. ${ }^{66}$ Cell to cell variability in alkaline phosphatase activity is also found in other species which experienced different degrees of phosphate stress under the same environmental conditions. ${ }^{67}$ This variability of expression of stress in phosphate is reported to be linked to the physiology of cell and in particular to the internal nutrient concentration. ${ }^{68-72}$ This internal stock of phosphate was particularly important in the Tetraselmis subcondiformis species and it is reported to support cell growth and maintain metabolic activity when extracellular phosphorus is depleted. ${ }^{73}$ The constitution of the storage is also probably rapid because some Tetraselmis species are reported to grow on very low phosphate concentration and take advantage of phosphate spike at a rates 
$2 \sim 3$ orders of magnitude faster than its growth rate. ${ }^{74}$ According to these previous studies, we suggest that presence-absence of labelling for some cells can not be exclusively explained by external concentration of DIP but may be in part due to the intracellular phosphate pool. This hypothesis addresses the importance of age of the culture or sample with regards to the interpretation of nutrient acquisition.

Due to these variations in alkaline phosphatase expression through the time, we investigated the alkaline phosphatase activity of Tetraselmis sp. in batch culture during 9 days. The growth of Tetraselmis sp. in the culture mainly started from the D1 and suggested that cells adapted to the high phosphorus concentration. A part of the most fragile cells (e.g., phosphorus-starved cell) probably lyses within a 1 day and release DOP in the medium. Growth curves of the culture (Figure 4) indicates that alkaline phosphatase activity occurs during the log phase of growth and was in agreement with the study of Meseck et al. ${ }^{59}$ The growth of Tetraselmis sp. and the decrease of the DIP concentration indicate that DIP is used as a source of phosphorus in the culture (Figure 4). According to the decrease of the DIP concentration, an increase of the number of labelled cells is expected as the culture is ageing. However, the ELF labelled cells are only observed during three days (D4, D5, D6). The decrease of DOP concentrations during these three days confirmed that some Tetraselmis sp. cells consumed some organic phosphorus compounds. From the D7 to the D9, lack of labelled cells in droplet appeared simultaneously to the increase of DOP suggesting that culture enters in its decay phase. The decay phase of the culture is confirmed by the decrease of the concentration of Tetraselmis sp. and the presence of cell aggregates observed in the culture. The increase of the DOP concentration can be linked to lysed cells which released both DOP and alkaline phosphatase enzymes in the culture. The release of alkaline phosphatase in the medium is confirmed by the high activity of alkaline phosphatase measured in the dissolved part. Our method does not characterize to which extent the alkaline phosphatase found in the medium is coming from an active release of Tetraselmis sp. or from lysed cells. However, this high value of alkaline phosphatase measured in the dissolved fraction of the culture can lead to the inhibition of extracellular alkaline phosphatase at the surface of the cell and explain the absence of labelled cell from the D7 to D9. Experimental evidence of decrease of ELF-A labelled cells concomitant to an increase of APA in the dissolved fraction is also observed in the study of Ou et al. ${ }^{58}$ Although the exact origin of this extracellular alkaline phosphatase is unclear in our case, our results suggest that enzyme found in the dissolved fraction has an important role in the phosphorus cycle and contribute to the cell survival under orthophosphate starvation. 


\section{Conclusion}

We develop a microfluidic procedure to test and measure the alkaline phosphatase activity at the single cell level in microfluidic droplets. Our method integrates in a single microfluidic device encapsulation, incubation and enzymatic assay of single living cells in droplets. The system is usable for high-content screening of single cells and is applied here to monitor phytoplankton enzymatic activity. The results reveal that the kinetics of the alkaline phosphatase are highly variable under the same environmental conditions. These results highlight the importance of single cell analysis to understand the ecophysiology of each cell which is commonly hidden by a measurement at the community level. The lack of extracellular phosphatase activity measured at the low inorganic phosphorus concentration suggests that high activity of free-enzyme may inhibit the extracellular alkaline phosphatase activity of the cells. However, additional efforts should be done to identify if this free alkaline phosphatase results from lysed cells or plankton secretion under orthophosphate starvation. These results highlight the importance of single cell analysis to understand the physiology of cells within a culture at the population level, but it also opens up an entire new package of opportunities for conducting physiological studies of each species present within a natural community assemblage.

\section{ASSOCIATED CONTENT}

\section{Supporting Information}

Figure S1. Kinetic analysis of APA using the multiple-concentration method in samples.

Figure S2. Bleaching of Tetraselmis sp. labelled with the enzyme labelled fluorescent method as a function of time and depending of the type of excitation.

Figure S3. Fluorescence spectra of Tetraselmis sp. labelled or not with the enzyme labelled fluorescence method.

Figure S4. Gaussian noise of the camera focussing on droplets containing medium and droplets with ELF-P substrate lacking Tetraselmis sp.

Figure S5. Fluorescence values calculated for a single cell labelled depending on the focusing plane.

Figure S6. Confocal microscopic images of a Tetraselmis sp. cell that is ELF labelled.

Figure S7. Variability of the labelling kinetic of Tetraselmis sp. including the lag period under the same environmental conditions. 


\section{AUTHOR INFORMATION}

\section{Corresponding Author}

*girault.bmi@gmail.fr

\section{Author Contributions}

The manuscript was written through contributions of all authors. All authors have given approval to the final version of the manuscript.

\section{Notes}

The authors declare that they have no competing interests.

\section{ACKNOWLEDGMENT}

We are grateful to Lycée de la Mer de Gujan-Mestras for giving us the culture of Tetraselmis sp. We acknowledge the financial support by the ERC (FP7/2007-2013 /ERC Grant agreement 306385 SofI), by the 'Région Aquitaine' and by the French Government 'Investments for the Future' Programme, University of Bordeaux Initiative of Excellence (IDEX Bordeaux) (Reference Agence Nationale de la Recherche (ANR)-10-IDEX-03-02). 


\section{REFERENCES}

(1) Platt, T.; Fuentes-Yaco, C.; Frank, K. T. Nature 2003, 423, 398- 399

(2) Britten, G. L.; Dowd, M.; Worma, B. Proc. Natl. Acad. Sci. USA 2016, 113, 134- 139

(3) Geider, R. J.; Delucia, E. H.; Falkowski, P. G.; Finzi, A. C.; Grime, P.; Grace, J.; Kana, T. M.; La Roche, J.; Long, S. P.; Osborne, B. A.; Platt, T.; Prentice, I. C.; Raven, J. A.; Schlesinger, W. H.; Smetacek, V.; Stuart, V.;

Sathyendranath, S.; Thomas, R. B.; Vogelmann, T. C.; Williams, P.; Woodward, F. I. Glob. Change Biol. 2001, $7,849-882$

(4) Behrenfeld, M. J.; O’Malley, R. T.; Siegel, D. A.; McClain, C. R.; Sarmiento, J. L.; Gene, C.; Feldman, G. C.; Milligan, A. J.; Falkowski, P. G.; Letelier, R. M.; Boss., E. S. Nature 2006, 444, 752- 55

(5) Capotondi, A.; Alexander, M. A.; Bond, N. A.; Curchitser, E. N.; Scott, J. D. J. Geophys. Res. 2012, 117, C04031, DOI: 10.1029/2011JC007409

(6) Fu, W.; Randerson, J. T.; Moore, J. K. Biogeosciences 2016, 13, 5151- 5170

(7) Labry, C.; Delmas, D.; Herbland, A. J. Exp. Mar. Biol. Ecol. 2005, 318, 213- 225

(8) Ruttenberg, K. C.; Dyhrman, S. T. Front. Microbiol. 2012, 3, 274, DOI: 10.3389/fmlcb.2012.0074

(9) McLaughlin, K.; Sohm, J. A.; Cutter, G. A.; Lomas, M. W.; Paytan, A. Global Biogeochem. Cycles 2013, 27, $375-387$

(10) Dyhrman, S., T.; Palenik, B. Appl. Environ. Microbiol. 1999, 65, 3205- 3212

(11) Hoppe, H. G. Hydrobiologia 2003, 493, 197-200

(12) Girault, M.; Arakawa, H.; Hashihama, F. J. Plankton Res. 2013, 35, 146- 157

(13) Fuentes, S.; Wikfors, G. H.; Meseck, S. Estuar. Coast. 2014, 37, 312- 324

(14) Ivančić, I.; Pfannkuchen, M.; Godrijan, J.; Djakovac, T.; Pfannkuchen, D. M.; Korlević; M.; Gašparović, B.; Najdek, M. Prog. Oceanogr. 2016, 146, 175- 186

(15) Lomas, M. W.; Swan, A.; Shelton, R. Limnol. Oceanogr. 2004, 49, 2303- 2310

(16) Duhamel, S.; Dyhrman, S. T.; Karl, D. M. Limnol. Oceanogr. 2010, 55, 1414- 1425

(17) Duhamel, S.; Björkman, K. M.; Van Wambeke, F.; Moutin, T.; Karl, D. M. Limnol. Oceanogr. 2011, 56, $1244-1254$

(18) Ly, J.; Philippart, C. J. M.; Kromkamp, J. C. J. Sea Res. 2014, 88, 109- 120 
(19) Van Wambeke, F.; Nedoma, J.; Duhamel, S.; Lebaron, P. Aquat. Microb. Ecol. 2008, 52, 245- 251

(20) Martínez-Soto, M. C.; Basterretxea, G.; Garcés, E.; Anglès, S.; Jordi, A.; Tovar-Sánchez, Front. Mar. Sci. 2015, 2, 54, DOI: 10.3389/fmars.2015.00054

(21) Nedoma, J.; Strojsová, A.; Vrba, J.; Komárková, J.; Simek, K. Environ. Microbiol. 2003, 5, 462- 472

(22) Kim, H. S.; Weiss, T. L.; Thapa, H. R.; Devarenne, T. P.; Han, A. Lab Chip 2014, 14, 1415- 1425

(23) Kim, H. S.; Devarnne, T. P.; Han, A. Lab Chip 2015, 15, 2467- 2475

(24) Luke, C. S.; Selimkhanov, J.; Baumgart, L.; Cohen, S. E.; Golden, S. S.; Cookson, N. A.; Hasty, J. ACS Synth. Biol. 2016, 5, 8-14

(25) Holcomb, R.; Mason, L. J.; Reardon, K. F.; Cropek, D. M.; Henry, C. S. Anal. Bioanal. Chem. 2011, 400, $245-253$

(26) Whitesides, G. M. Nature, 2006, 442, 368-373

(27) Karle, M.; Vashist, S. K.; Zengerie, R.; Stetten, F. V. Anat, Chim. Acta 2016, 929, 1- 22

(28) Miller, E. M.; Wheeler, A. R. Anal. Chem. 2008, 80, 1614- 1619

(29) Beneyton, T.; Thomas, S.; Griffiths, A. D.; Nicaud, J.-M.; Drevelle, A.; Rossignol, T. Microb. Cell Fact. 2017, 16, 18. DOI: 10.1186/s12934-017-0629-5

(30) Baret, J. C.; Miller, O. J.; Taly, V.; Ryckelynck, M.; El-Harrak, L.; Frenz, L.; Rick, C., Samuels, M. L.; Hutchison, J. B., Agresti, J. J.; Link, D. R.; Weitz, D. A.; Griffiths, A. D. Lab Chip 2009, 7, 1850- 1858

(31) Brouze, E.; Medkova, M; Savenelli, N; Marran, D.; Twardowski, M.; Huthison, J. B.; Rothberg, J. M.; Link, D. R.; Perrimon, N; Samuels, M. L. Proc. Natl. Acad. Sci. U.S.A. 2009, 106, 14195- 14200

(32) Song, H.; Chen, D. L.; Ismagilov, R. F. Angew. Chem. 2006, 45, 7336- 7356

(33) Mazutis, L.; Baret J.-C.; Treacy, P.; Skhir, Y.; Araghi, A. F.; Ryckelynck, M.; Taly, V.; Griffiths, A. D Lab Chip 2009, 9, 2902-2908

(34) Parke, M. J. Mar. Biol. Assoc. U.K. 1949, 28, 255- 288

(35) Mao, Z.; Guo, F.; Xie, Y.; Zhao, Y.; Lapsley, M. I.; Wang, L.; Mai, J. D.; Costanzo, F.; Huang, T. J. J. Lab. Autom. 2015, 20, 17- 24

(36) Guillard, R. L.; Ryther, J. H. Can. J. Microbiol. 1962, 8, 229-239

(37) Cho, J. Y.; Choi, J. S.; Kong, I. S.; Park, S. I.; Kerr, R. G.; Hong, Y. K. J. Appl. Phycol. 2002, 14, 385- 390

(38) Duffy, D. C.; McDonald, J. C.; Schueller, O. J.; Whitesides, G. M. Anal. Chem. 1998, 70, 4974- 4984 
(39) Girault, M.; Hattori, A.; Kim, H.; Arakawa, H.; Matsuura, K.; Odaka, M.; Terazono, H.; Yasuda, K. Sci. Rep. 2017, 7, 40072, DOI: 10.1038/srep40072

(40) Anna, S. L.; Bontoux, N.; and Stone, H. A. Appl. Phys. Lett. 2003, 82, 364- 366

(41) Frenz, L.; Blank K.; Brouzes, E.; Griffiths, A. D. Lab Chip 2009, 9, 1344- 1348

(42) Valderrama, J. C. Marine Chemistry 1981, 10, 109- 122

(43) Murphy, J.; Riley, J. P. Anal. Chim. Acta 1962, 27, 31-36

(44) Huang, Z.; Terpetschnig, E.; You, W.; Haugland, R. P. Anal. Biochem. 1992, 207, 32- 39

(45) González-Gil, S.; Keafer, B.; Jovine, R. V. M.; Anderson, D. M. Mar. Ecol. Prog. Ser. 1998, 164, 21- 35

(46) Huebner, A.; Olguin, L. F.; Bratton, D.; Whyte, G.; Huck, W. T. S.; De Mello, A. J.; Edel, J. B.; Abell, C.; Hollfelder, F. Anal. Chem. 2008, 80, 3890- 3896

(47) Shim, J.-Uk; Olguin, L. F.; Whyte, G.; Scott, D.; Babtie, A.; Abell, C.; Huck, W. T. S.; Holifelder, F. J. Am. Chem. Soc. 2009, 131, 15251- 15256

(48) Obayashi, Y.; Lino, R.; Noji, H. Analyst 2015, 140, 5065- 5073

(49) Chen, S.; Zhao, M.; Wu, G.; Yao, C.; Zhang, J. Comput. Math. Methods Med. 2012, DOI: $10.1155 / 2012 / 101536$

(50) Girault, M.; Odaka M.; Kim, H.; Matsuura, K.; Terazono, H.; Yasuda, K. JPN. J. Appl. Phys. 2016, 55, DOI: 10.7567/JJAP.55.06GN05

(51) Nedoma, J.; Van Wambeke, F.; Strojsová, A.; Strojsová, M.; Duhamel, S. Mar. Freshwater Res. 2007, 58, $454-460$

(52) Wynne, D. Hydrobiologia 1981, 83, 93-99

(53) Jansson, M.; Olsson, H.; Pettersson, K. Hydrobiologia 1988, 170, 157- 175

(54) Li, H.; Veldhuis, M. J. W.; Post, A. F. Mar. Ecol. Prog. Ser. 1998, 173, 107- 115

(55) Oh, S. J.; Yoon, Y. H.; Yamamoto, T.; Matsuyama, Y. Ocean Sci. J. 2005, 40, 183- 190

(56) Bar-Yosef, Y.; Sukenik, A.; Hadas, O.; Viner-Mozzini, Y.; Kaplan, A. Curr. Biol. 2010, 20, 1557- 1561

(57) Wang, P. F.; Ren, L. X.; Wang, C.; Qian, J.; Hou, J. J. Limnol. 2015, 74, 155- 168

(58) Ou, L.; Huang, B.; Hong, H.; Qi, H.; Lu, S. J. Phycol. 2010, 46, 260- 265

(59) Meseck, S. L.; Alix, J. H.; Wikfors, G. H.; Ward, J. E. Estuar. Coast. 2009, 32, 1195- 1204

(60) Diaz de Quijano, D.; Felip, M. J. Microbiol. Methods 2011, 86, 104- 107 
(61) Brandes, D.; Elston, R. N. Nature 1956, 177, 274- 275

(62) Kuenzler, E. J.; Perras, J. P. Biol. Bull. Mar. Biol. Lab. Woods Hole 1965, 128, 271- 284

(63) Moller, M.; Myklestad, S.; Haug, A. J. Exp. Mar. Biol. Ecol. 1975, 19, 217- 226

(64) Wynne, D. Physiol Plant. 1977, 40, 219-224

(65) Flynn, K. J.; Opic, H.; Syrett, P. J. J. Gen. Microbiol. 1986, 132, 289- 298

(66) Lin, S.; Litaker, R. W.; Sunda, W. G. J. Phycol. 2016, 52, 10- 36

(67) Rengefors, K.; Ruttenberg, K. C.; Haupert, C. L.; Taylor, C.; Howes, B. L.; Anderson, D. M. Limnol. Oceanogr. 2003, 48, 1167- 1175

(68) Myklestad, S.; Sakshaug, E. J. Plankton Res. 1983, 5, 557- 564

(69) Gage, M. A.; Gorham, E. Fresh. Biol. 1985, 15, 227- 233

(70) John, E. H.; Flynn, K. J. Ecol. Modell. 2000, 125, 145- 157

(71) Rengefors, K.; Pettersson, K.; Blenckner, T.; Anderson, D. M. J. Plankton Res. 2001, 23, 435- 443

(72) Nicholson, D.; Dyhrman, S.; Chavez, F.; Paytan., A. Limnol. Oceanogr. 2006, 51, 874- 883

(73) Yao, C. H.; Ai, J. N.; Cao, X. P.; Xue, S. Appl. Microbiol. Biotechnol. 2013, 97, 6099-6110

(74) Laws, E. A.; Pei, S.; Bienfang, P.; Grant, S. Aquaculture 2011, 322-323, 117- 121 


\section{Supporting information for:}

\section{High-content screening of plankton alkaline phosphatase activity in microfluidics}

Mathias Girault*1, Thomas Beneyton ${ }^{1}$, Deniz Pekin ${ }^{1}$, Lionel Buisson ${ }^{1}$, Sabrina Bichon ${ }^{1}$, Céline Charbonnier ${ }^{2}$, Yolanda del Amo ${ }^{2}$, Jean-Christophe Baret ${ }^{1}$

1) CNRS, Univ. Bordeaux, CRPP, UMR5031, 33600 Pessac, France.

2) CNRS, Laboratoire d'Environnements et Paléoenvironnements Océaniques et Continentaux (EPOC), UMR 5805, 33615 Pessac, France.

*Corresponding author: girault@ crpp-bordeaux.cnrs.fr

\section{Table of Contents:}

Figure S1. Kinetic analysis of APA using the multiple-concentration method in samples.

Figure S2. Bleaching of Tetraselmis sp. labelled with the enzyme labelled fluorescent method as a function of time and depending of the type of excitation.

Figure S3. Fluorescence spectra of Tetraselmis sp. labelled or not with the enzyme labelled fluorescence method.

Figure S4. Gaussian noise of the camera focussing on droplets containing medium and droplets with ELF-P substrate lacking Tetraselmis sp.

Figure S5. Fluorescence values calculated for a single cell labelled depending on the focusing plane.

Figure S6. Confocal microscopic images of a Tetraselmis sp. cell that is ELF labelled.

Figure S7. Variability of the labelling kinetic of Tetraselmis sp. including the lag period under the same environmental conditions. 


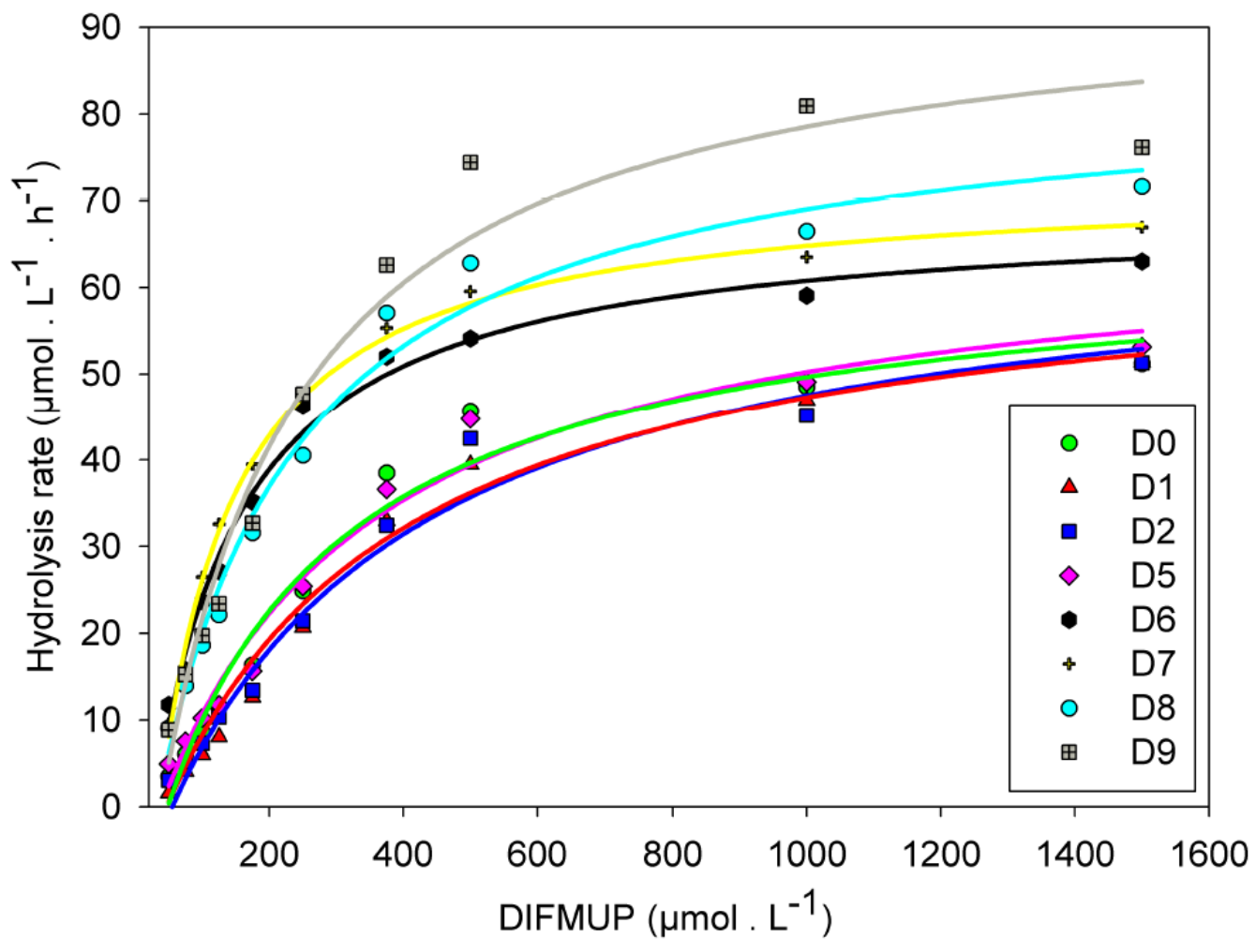

Figure S1: Kinetic analysis of alkaline phosphatase activity (APA) using the multipleconcentration method in samples. APA as a function of added DIFMUP concentration using Michaelis-Menten kinetics. 


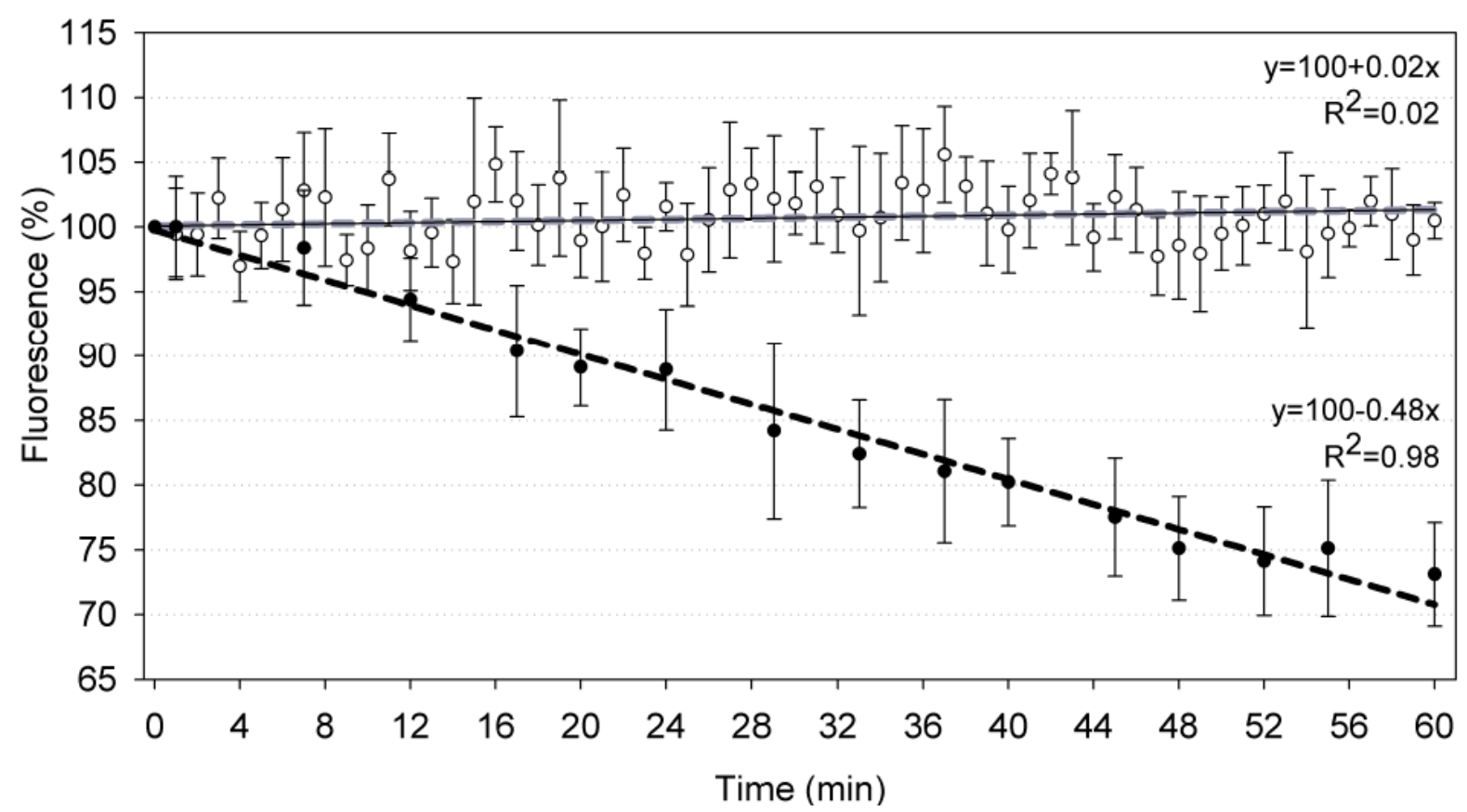

Figure S2: Bleaching of fluorescent labelled Tetraselmis sp. as a function of time and type of excitation (365 nm, $\mathrm{n}=12$ ). White dots correspond to an excitation time of $500 \mathrm{~ms} /$ each $30 \mathrm{~s}$. The black dots correspond to a continuous excitation by the UV LED. 


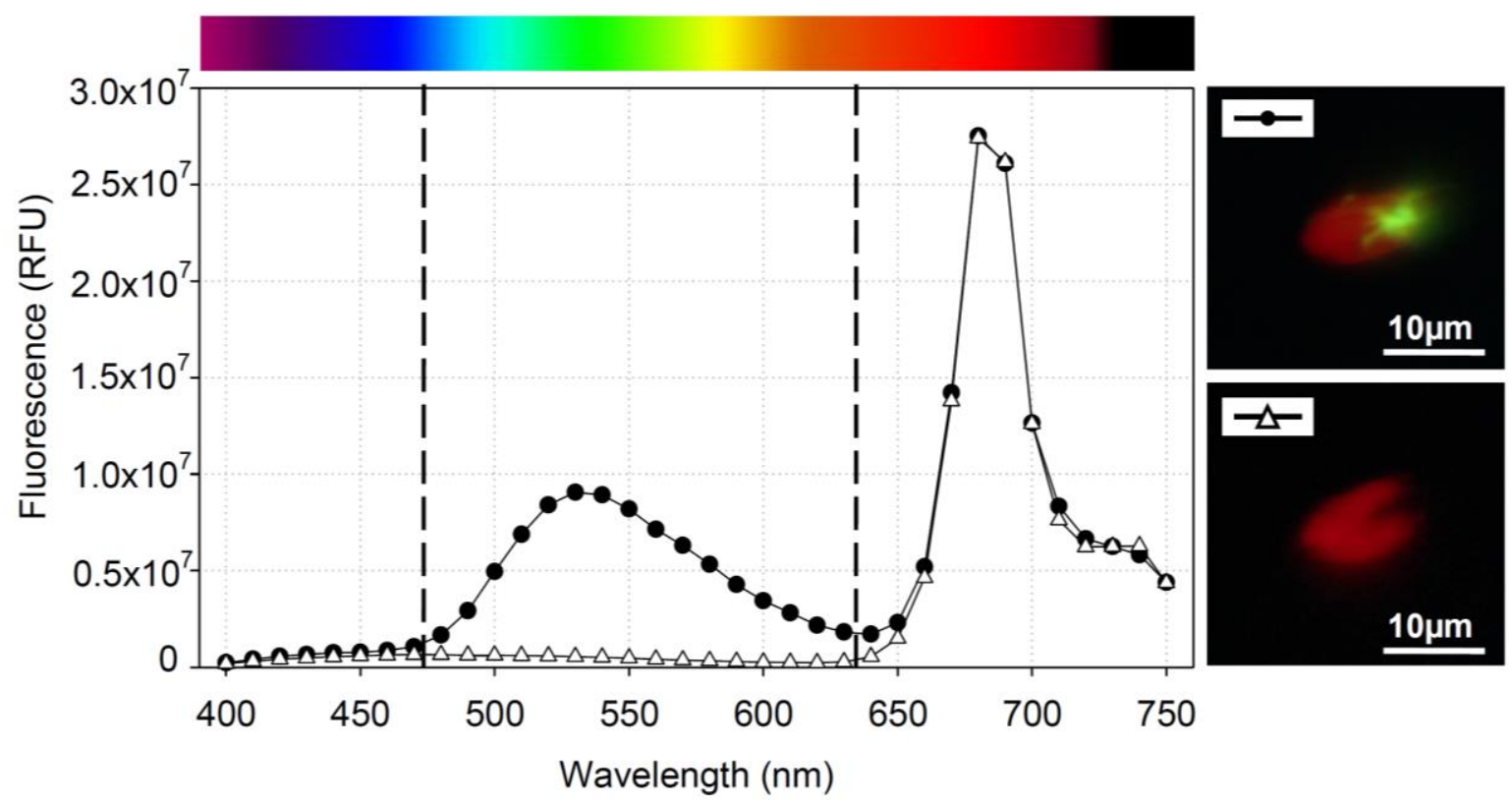

Figure S3: Fluorescence spectra of Tetraselmis sp. labelled (black dots) or not (white triangles) with the enzyme labelled fluorescence method (ex: $365 \mathrm{~nm}$ ). The dashed lines show the optical threshold of mirrors used to extract the green label. 


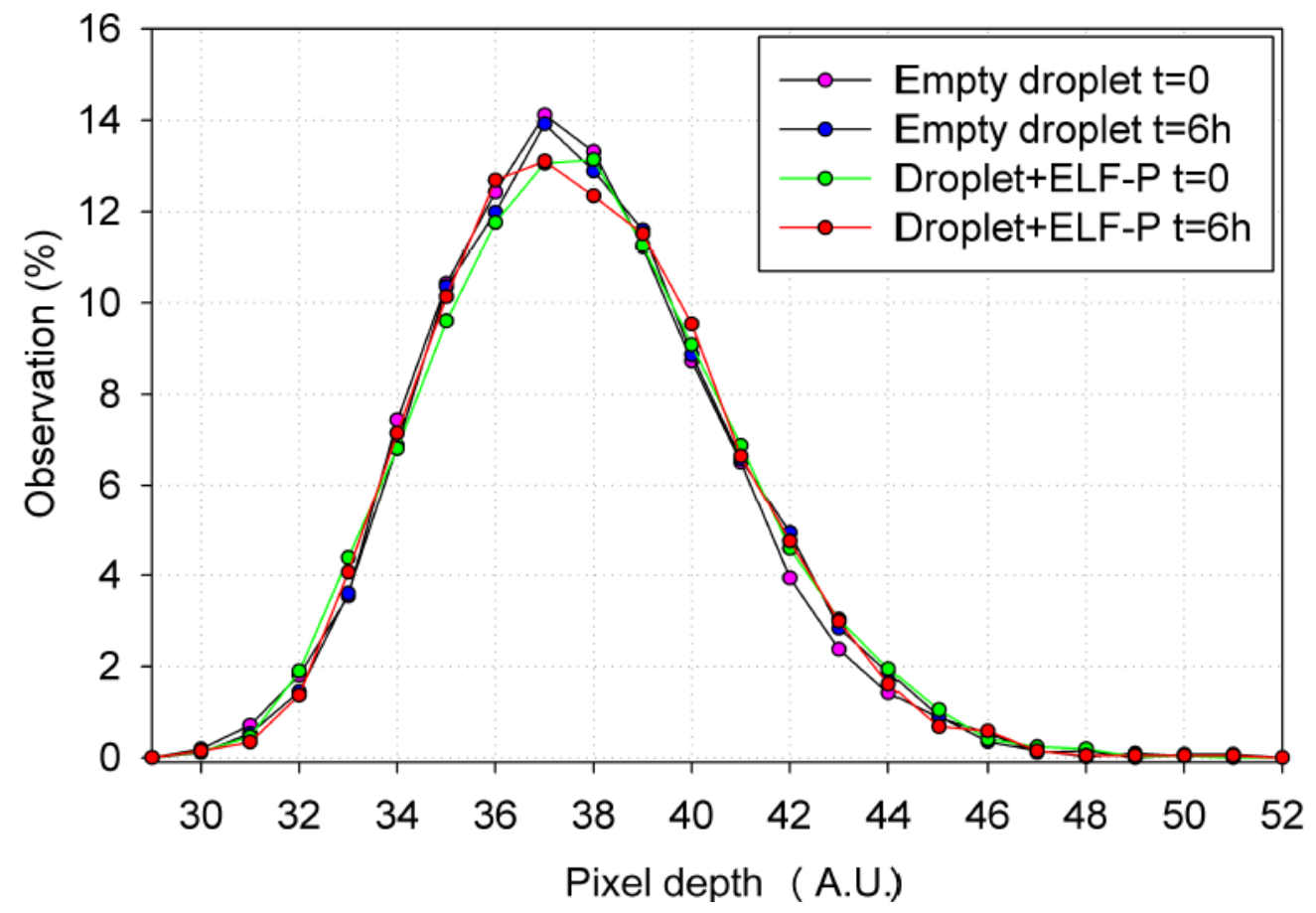

Figure S4: Gaussian noise of the camera focussing on droplets containing medium and droplets with ELF-P substrate lacking Tetraselmis sp. Autohydrolysis of ELF-P substrate is not observed after 6 hours exposed at $365 \mathrm{~nm}$. 


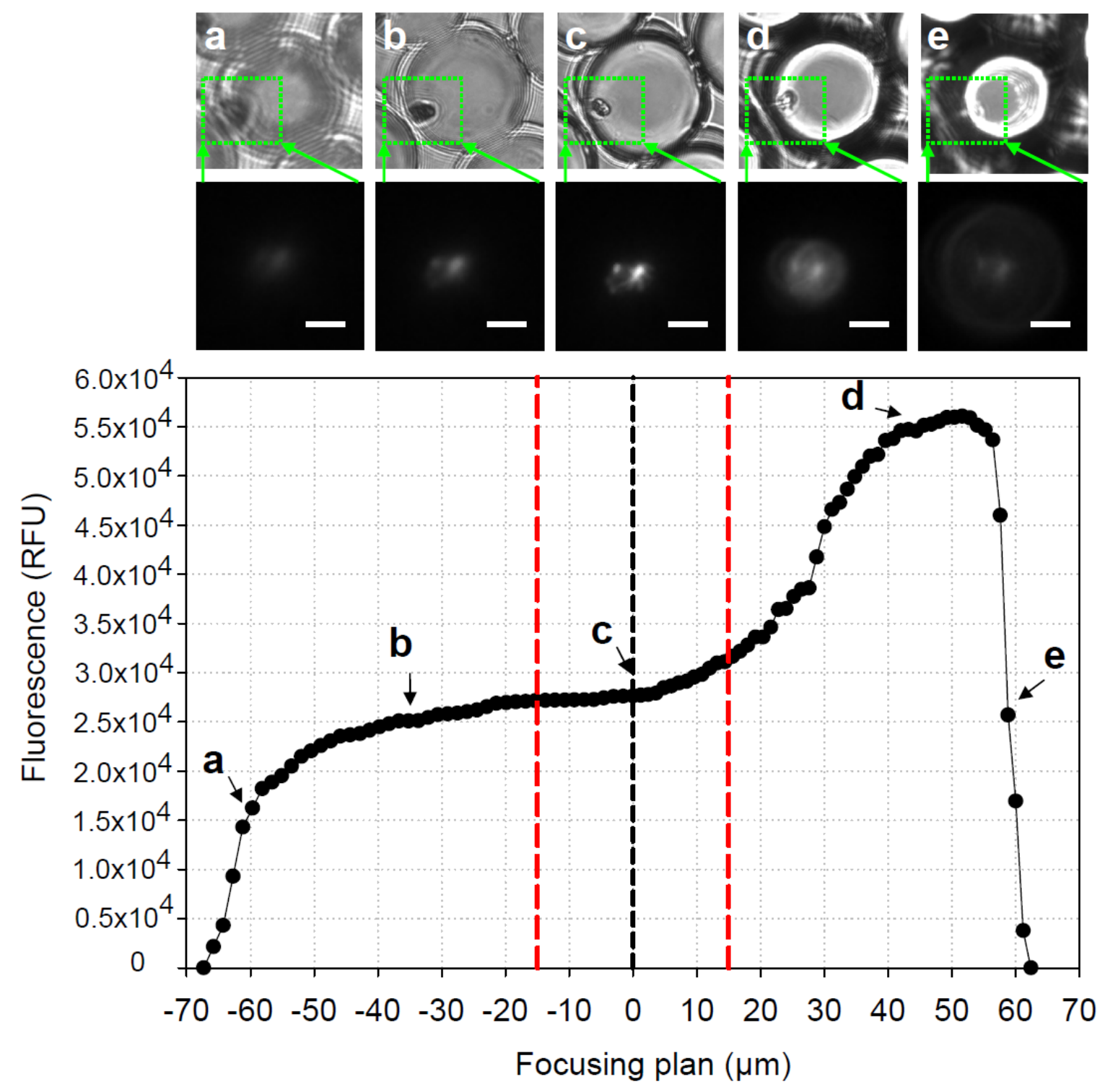

Figure S5: Fluorescence values calculated for a single cell labelled depending on the focusing plane. The black and the red dashed lines show the optimal focusing plane and the limit of the channel depth. The photomicrographs (a) and (b) illustrate the cases where the focusing plane is under the optimal focusing plane (c). The photomicrographs (d) and (e) illustrate the cases where the focusing plane is upper the optimal focusing plane (c). White lines are the $10 \mu \mathrm{m}$ scale bars. 

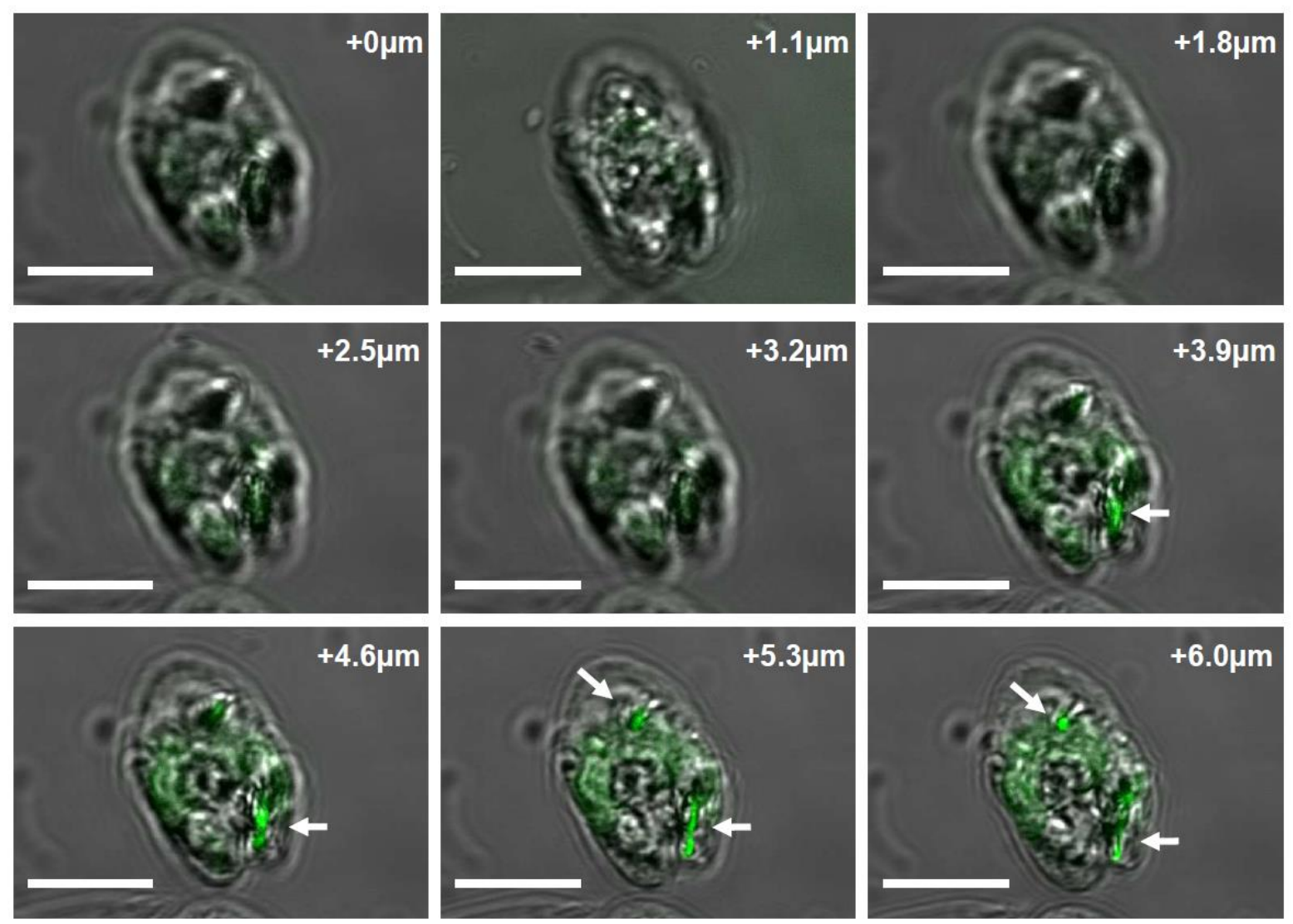

Figure S6: Confocal microscopic images of a Tetraselmis sp. cell that was ELF labelled. Numbers in the pictures represent different scanning depths. The white arrows represent the two sites of the alkaline phosphatase at or near the cell surface. A diffuse green fluorescence signal observed inside the cell is linked to the pigment content of the cell. Length of scale bars is $5 \mu \mathrm{m}$. 


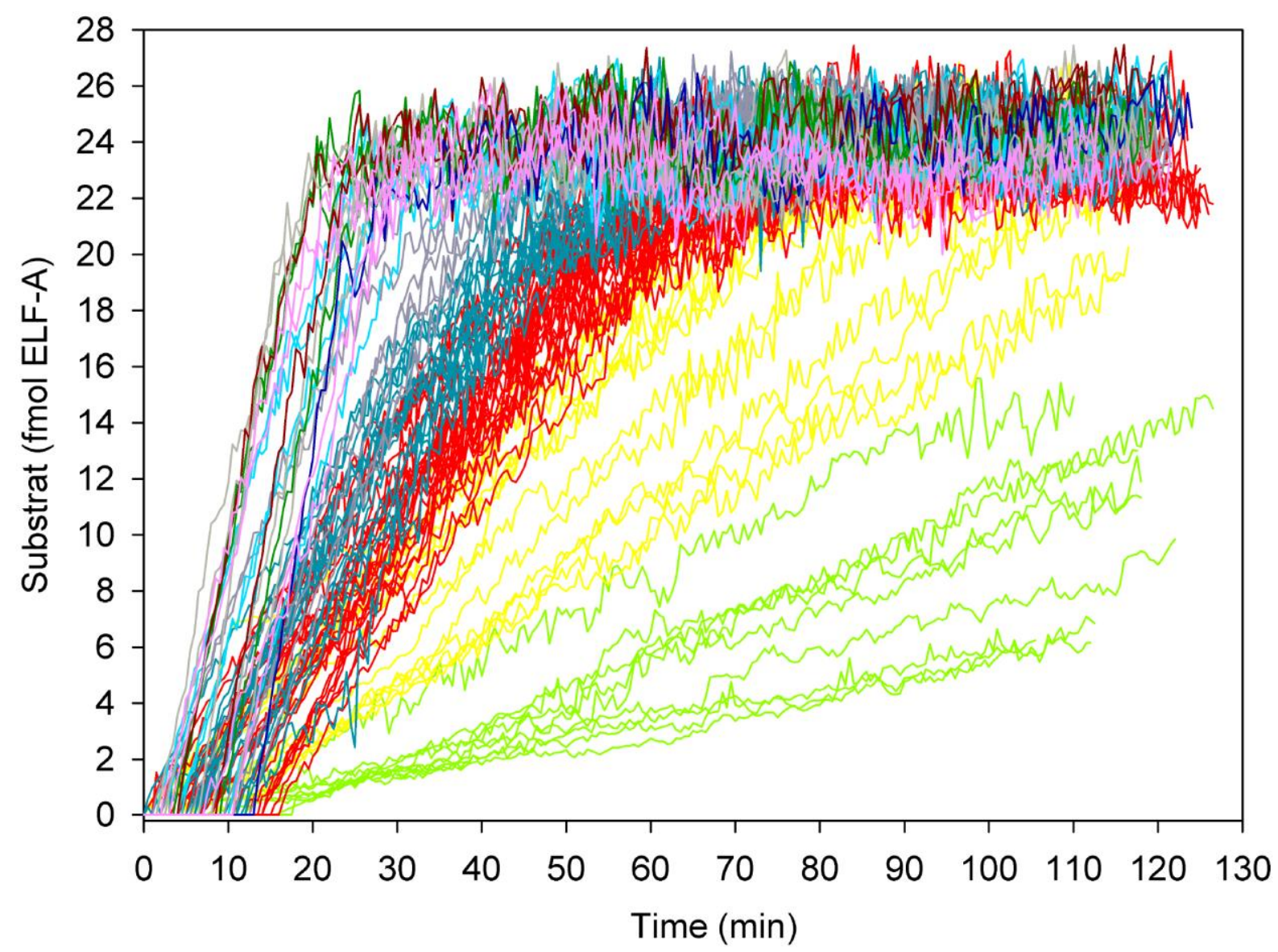

Figure S7: Variability of the labelling kinetic of Tetraselmis sp. including the lag period under the same environmental conditions. 